\title{
Shared housing for students and young professionals: evolution of a market in need of regulation
}

This is an author-produced PDF of an article accepted following peer review for publication in Journal of Housing and the Built Environment (https://doi.org/10.1007/s10901-020-09778-w).

Constance Uyttebrouck*1, Ellen van Bueren**, Jacques Teller*

*Urban and Environmental Engineering Department, University of Liège, Liège, Belgium; **Department of Management in the Built Environment, Delft University of Technology, Delft, the Netherlands

Abstract: This research addresses the shared housing market, that is, large-scale developments targeting students and 'young professionals', equipped with shared spaces and services for the residents. This housing segment has emerged in response to young adults' demand for flexible and affordable housing. It has developed in cities that concentrate students and young single professionals, plan densification strategies and face housing commodification. We specifically explore the production side of this market, through the comparison of two projects in Amsterdam. Our objective is to understand the institutional context in which these projects were developed and their outcomes. Consequently, the research questions are: which actors develop these projects, what instruments do they use, and what are the outcomes in a commodifying housing market? From our analysis, the actors need to collaborate on shared housing developments and receive support from local governments, through the strategic use of planning instruments and tenure regulations. However, the shared facilities seem to merely serve to commercialize small housing production, while housing affordability and accessibility are threatened. We, thus, recommend local and national authorities to regulate the provision of shared spaces and suggest further research on the effects of the shared housing market in cities facing housing commodification.

Keywords: Commodification, Institutional framework, Regulation, Shared housing, Young professionals

\footnotetext{
${ }^{1}$ Corresponding author: Urban and Environmental Engineering dept., ULiège, B52, 9 allée de la Découverte, 4000 Liège, Belgium - Tel. : +32 472387995 - e-mail : constance.uyttebrouck@uliege.be
} 


\section{Introduction}

This research addresses a new form of shared housing, the shared housing market, that is, largescale developments delivering a substantial number of small housing units (up to 900 units starting from $25 \mathrm{~m}^{2}$ in this study), equipped with shared spaces and services (e.g., libraries, working spaces) for the residents. This emerging housing segment has been increasingly supported by local governments and generally targets students (e.g., Thomsen, 2007) and 'young professionals' (Druta \& Ronald, 2020; Kemp, 2011). The latter are young (commonly defined as aged 20 to 34), often single and highly-educated adults, who are in the early stages of their careers and are expected to be flexible and mobile for their work (Bergan, Gorman-Murray, \& Power, 2020; Heath \& Kenyon, 2001). Shared housing providers do not necessarily exclude other target groups, but the focus is implicitly reflected in the tenant demographic (Bergan et al., 2020).

In response to young professionals' demand for flexible and affordable accommodation, the shared housing market has been developed throughout Europe, considering that shared facilities can compensate for smaller-and supposedly more affordable-dwellings (Verhetsel, Kessels, Zijlstra, \& Van Bavel, 2017). In countries such as the UK, young (single) professionals and students are the main drivers of inner-city and shared-housing developments (Bromley, Tallon, \& Roberts, 2007; CB Richard Ellis [CBRE], 2018; Hubbard, 2009). The emergence of this market is further facilitated in cities with a commodifying housing market, which seek to attract a target group through land-use strategies oriented towards densification.

Young adults' pathways towards a time of 'settling down' have been increasingly studied in the literature (e.g., Heath \& Kenyon, 2001; Hochstenbach \& Boterman, 2015; Hoolachan, McKee, Moore, \& Soaita, 2017), so have been their housing preferences (e.g., Nijënstein, Haans, Kemperman, \& Borgers, 2015; Verhetsel et al., 2017). However, less attention has been paid to the governance of the related housing segment, which first emerged as a response to the housing shortage for young adults in cities before being progressively institutionalised. As a result, institutional analysis of the shared housing market has been scarce so far. However, the new alliances of actors and their roles in the creation of this market require further investigation (Maalsen, 2020; Mackie, 2016). Therefore, our purpose is to explore, through the comparison of two projects located in Amsterdam, the development of the shared housing market. This fastgrowing Dutch city has a tremendous housing shortage, especially for students (Fang \& van Liempt, 2020) and young professionals (Hochstenbach \& Boterman, 2015). This situation is partly due to the internationalisation of higher education (Fang \& van Liempt, 2020) and young adults' preference for urban living (Muhammad, Ottens, Ettema, \& Jong, 2007). Amsterdam has also experienced an on-going restructuring of affordable housing provision, following housing policy changes making room for new, flexible tenure forms (Huisman, 2016b; Jonkman, 2020). 
Moreover, the municipality promotes densification as a tool of urban development, in line with national policies.

We have adopted an institutionalist approach (González \& Healey, 2005) in order to understand the actors' means and interests, and, in particular, the public sector's supporting role. We further reflect on the balance between shared facilities and small housing, and on affordability and accessibility outcomes, as two key issues for the target demographic. This paper, thus, addresses these questions: (i) which coalitions of actors develop shared housing projects, (ii) what instruments are used in this process and (iii) what are the outcomes on a commodifying housing market. The next section analyses the drivers of the shared housing market in Amsterdam. We then present our analytical framework and discuss the results prior to the conclusions and recommendations.

\section{Understanding the drivers of a shared housing market in the Amsterdam context}

Three dimensions of the shared housing market are apparent in Amsterdam and examined here: (i) a growing share of students and young professionals, (ii) a commodifying housing market and (iii) a strong willingness to increase density in the city.

\subsection{Students and young professionals, shifting from 'generation rent' to 'generation share'}

Having moved to cities to complete higher education, young singles tend to stay for the first years of their careers (Booi \& Boterman, 2019). Amsterdam concentrates this fast-growing group (ibid), with one-person households representing half of the population, and one-third of all households being aged 20 to 34 (Onderzoek Informatie en Statistiek [OIS], 2017). Amsterdam's housing agenda 2025 (Woonagenda 2025) estimates that students and 'under 35, without children and with higher education' (i.e., young professionals - Gemeente Amsterdam, 2017, p. 34; authors' translation) will represent $15 \%$ of the population in 2025 and sets quantitative targets for this group (ibid). The concentration of young adults in urban areas has been linked to the development of the knowledge economy. The latter has also brought about a substantial highly-skilled working class, sometimes labelled as the 'creative class' (Florida, 2002). The creative talents conceptualised by Florida are assumed to live and work differently, being attracted to innovative environments and third places (Bontje, Musterd, \& Sleutjes, 2017). However, scholars have heavily questioned the idea that a unique creative class could drive urban economic development (e.g., Bontje \& Musterd, 2009). They have also denounced the myth of 'young, hip professionals' moving between locations with similar amenities (Bergan et al., 2020). In the Netherlands, the allegedly homogenous group of young adults entering the housing market was already questioned in the 1980s (Linde, Dieleman, \& Clark, 1986). Nevertheless, local authorities still rely upon 
these narratives, including in Amsterdam, where they inspire urban restructuring and housing policies (Hochstenbach, 2016).

Housing is key in young adults' transition to adulthood, as it impacts both quality of life and economic security (Arundel \& Ronald, 2016). Hoolachan et al. (2017) have designated young adults as 'Generation Rent' to emphasize their tendency to live in the private-rented sector (PRS) for ever-longer periods, especially in the aftermath of the 2008 financial crisis, making the time of 'settling down' more difficult for them to reach. Huisman (2016a) has introduced the notion of 'permanent temporariness' to refer to this emerging risk in the Netherlands. Young professionals are also one of the main target demographics for the shared-housing market (Bergan et al., 2020; Druta \& Ronald, 2020; Heath \& Kenyon, 2001; Landriscina, 2018; D. P. Smith \& Hubbard, 2014). Maalsen (2020) introduced, provocatively, the 'Generation Share' concept implying that shared housing is not so transient any longer. In Amsterdam, even more than in other Dutch cities, young adults face long waiting times for social housing (Amsterdamse federatie van woningcorporaties [AFWC], 2018). They are often neither eligible for social housing nor able to obtain a mortgage (Boelhouwer, 2019). These conditions, combined with stagnating housing production (ibid) and the growth of (international) students following higher education (Fang \& van Liempt, 2020), have contributed to the growing market pressure on the Dutch PRS and the housing shortage (Boelhouwer, 2019). Because it has become increasingly difficult for young adults to pursue a linear housing career in cities like Amsterdam (Hochstenbach \& Boterman, 2015), flexible life arrangements have expanded in Dutch cities (Hochstenbach, Wind, \& Arundel, 2020). Although young professionals are usually expected to value urban living (Fincher \& Costello, 2005; Muhammad et al., 2007), young singles show no intention to settle long term in Amsterdam (Booi \& Boterman, 2019). This is consistent with the introduction of short-term, flexible tenure forms in the shared housing market.

The next sub-section highlights how the recent development of the shared housing market has been facilitated in Amsterdam, and how housing policy has been adapted to facilitate temporary and flexible use. Beyond the need for (and constraint to) flexibility, these developments reflect a growing pressure to reduce the size of housing (Syntrus Achmea Real Estate \& Finance B.V., 2016).

\subsection{Temporary and ever-smaller housing on the rise in a changing housing market}

Amsterdam has a long tradition of social housing, a fully rental market offered by non-profit and financially independent housing associations (Boterman \& van Gent, 2014). The latter hold over $40 \%$ of the total housing stock (Hochstenbach \& Ronald, 2020) and are also the main providers of student housing through 'campus contracts' (see below for details). The Dutch housing regulations have been affected by welfare state restructuring since the 1990 s (e.g., Kadi \& 
Musterd, 2015). Since 2012, housing associations have to focus on housing primarily the lowincome groups, whereas they previously accommodated a variety of income groups (Boelhouwer \& Priemus, 2014), making this sector hardly accessible for young professionals. Moreover, housing associations are no longer allowed to develop mixed tenure or commercial activities (e.g., Nieboer \& Gruis, 2016), which requires them to collaborate with other parties for mixed-use developments. Another important change in Dutch regulation is the emergence of short-term or 'temporary' rental contracts, both in the PRS and for social housing, whereas the norm used to be indefinite contracts with regulated rents (Huisman, 2016a). In the late 1990s, 'campus contracts' were introduced to tackle the scarcity of affordable housing for students (Huisman, 2016b). More recently (2016), temporary, short-term rental contracts (from 2 to 5 years) were also approved for other target groups, including young professionals, with a focus on dwellings smaller than $40-50$ $\mathrm{m}^{2}$ (AFWC, 2016).

The Dutch housing market thus has been partly deregulated with the progressive retreat of housing associations and the emergence of less secure forms of tenure. Housing deregulation has contributed to housing 'commodification'-i.e., the utilization of housing as an asset (Madden \& Marcuse, 2016). This trend was facilitated by 'entrepreneurial states' (Mazzucato, 2013) and has permitted more influence of institutional investors (Theurillat, Rérat, \& Crevoisier, 2015). In Amsterdam, the housing market was deeply impacted by the 2008 crisis, leading to decreased property values (Nieboer \& Gruis, 2016). Nevertheless, tremendous increase in property prices (from $€ 200,000$ in 2015 to $€ 319,000$ in 2018) have been observed in the aftercrisis recovery, placing Amsterdam well above the Dutch average, especially given the small size of Amsterdam dwellings (Hochstenbach \& Arundel, 2019, p. 12). This has led to higher values in every segment, including in the PRS (Onderzoek Informatie en Statistiek [OIS], 2017), which has fuelled housing affordability issues in the city.

In contexts under commodification, the opportunity to develop very profitable small apartments, especially for students and young professionals, has emerged. This development has been observed internationally, for example with inner-city, high-rise developments built for students and affluent, childless young professionals in the UK (Bromley et al., 2007; Hubbard, 2009). To our knowledge, little research of the shared housing market has been conducted in Dutch cities so far, although different forms of 'resurgent landlordism' have been investigated in student cities (e.g., in Groningen, see Hochstenbach et al., 2020). Nonetheless, this phenomenon is well present in Amsterdam, where the number of studios produced more than tripled between 2012 and 2016 and represented 40\% of all newly built accommodations in 2016 (Onderzoek Informatie en Statistiek [OIS], 2017). Besides, the municipality monitors 'youth' and 'student' housing (34,000 housing units in total in 2019 - Gemeente Amsterdam, 2019). Amid these developments, 25 properties concern both students and young professionals and were planned and developed either by housing associations (44\%), market parties (40\%), or a coalition of both 
types of actors (16\%) (ibid). No data is available on the presence of shared facilities in these properties though. Moreover, despite recent investigations of the 'buy-to-let' sector (Hochstenbach \& Ronald, 2020), the tenure forms of these new housing developments are underdocumented so that 'an important shift in the Dutch rental system has gone unobserved' (Huisman, 2016a, p. 102).

The reduction in housing size has encouraged the development of new forms of shared housing, including the shared housing market. Sharing is expanding in a situation of investmentdriven PRS, fast-growing prices and reduced social housing provision (Maalsen, 2020). The initially innovative concept of sharing common spaces-e.g., a kitchen-was repurposed by the market through the development of new real estate practices, to meet students and young professionals' perceived needs (Pfeiffer et al., 2019). In Amsterdam, the shared housing market is likely to contribute to the on-going commodification of the housing market and fuel the debate on housing affordability and accessibility issues.

\subsection{Shared facilities as a way to legitimize densification through small housing}

Densification has become central to urban development strategies in large European cities. Mixed-use developments, with amenities, are advocated in the public discourse to bring liveability to the built environment and to attract highly-skilled workers. The major Dutch cities have applied densification policies, which has led most housing developments to take place within existing urban boundaries since 2012 (Dembski, Hartmann, Hengstermann, \& Dunning, 2020; Meijer \& Jonkman, 2020; Nabielek, 2011). However, different spatial patterns have been observed locally, especially since planning policies have become decentralised (Meijer \& Jonkman, 2020; Nabielek, 2011). Amsterdam emphasizes the provision of attractive living places as part of its investment in higher education institutes, which encourages a regular influx of highly-educated workers and knowledge companies (Bontje \& Musterd, 2009; Hochstenbach, 2016). The city has a strong economic position (Bontje et al., 2017), including in knowledgeintensive sectors. Amsterdam is also actively involved in land-use planning with more than $80 \%$ of publicly-owned land, which is leased-out through a specific instrument: the land-lease contract (erfpacht) (Savini, Boterman, van Gent, \& Majoor, 2016). The municipality works closely with builders, developers, housing associations and residents (Buitelaar \& Sorel, 2010; Savini, 2016), but has tended to prioritize market interests since the financial crisis (Savini, 2016).

Amsterdam's structural vision (Structuurvisie Amsterdam 2040) and the Amsterdam 2025 strategy (Koers 2025) both illustrate how densification and mixed-use development have been chosen as a way to develop the city in response to land scarcity, social control issues and the need to increase the housing supply (Bontje et al., 2017; Hochstenbach, 2016; Savini et al., 2016).

The emergence of the shared housing market is supported by the municipality, given the 
aforementioned housing shortage for young adults. However, the development of youth and student housing can lead to 'youthification' and 'studentification', i.e. the creation of exclusionary spaces following the expansion of youth and student populations in particular neighbourhoods (Moos, 2016; Revington, Moos, Henry, \& Haider, 2018; D. P. Smith \& Hubbard, 2014). Young professionals can further impact gentrifying areas by enhancing the development of luxury mixeduse buildings (Landriscina, 2018). In a context of on-going commodification, we expect that the growing shared housing market is subject to similar risks in Amsterdam.

\subsection{Shared housing: analysis of a market from the perspective of its creators}

We have shown how Amsterdam, through its attractiveness for young single professionals, its commodifying housing market and its densification agenda, fosters the development of a particular housing market for students and young professionals. Previous work has paid much attention to studentification issues and young adults' housing pathways and preferences. Space sharing in community-led developments has become a well-established field of research as well (e.g., Tummers, 2016). Receiving less attention so far, has been the perspective of the actors who have used the concept of sharing to create a market-led housing segment (Maalsen, 2020; Mackie, 2016), and the genuine reasons for governments' support to these initiatives. Therefore, we examine the means and interests of the producers of the shared housing market, in Amsterdam, through the in-depth qualitative analysis of two illustrative developments.

\section{Analytical framework}

\subsection{Data and methods}

The two shared housing projects selected for this paper are joint initiatives between the market (institutional investor or developer) and the third sector (housing association). The project programmes are depicted in Sect. 4.1. The first project consists of the conversion of an office building into housing while the second project is a newly built housing development in a densification area of the structural vision. The two projects illustrate the desire of the municipality to enhance densification and mixed-use development. In particular, project 1 was chosen as a pioneering development with a tenure mix, scale and dwelling size unusual for the time. By comparison, project 2 is an example of evolution towards shared housing, with additional shared spaces and services for the residents, but comparable development scale. The offset in timelines (project 2 started much later than project 1) illustrates the evolution of the shared housing market, impacted by its institutional and economic contexts.

Table 1 details the empirical material collected and analysed. Interviewees have been anonymized and their statements are referred to following their designation in the table. Both 
buildings were visited and twelve in-depth, semi-structured interviews were conducted over the period of February-May 2018. We interviewed a representative of each of the main actor groups (private developer or investor, municipality, housing association, architect and residents). Based on the analytical framework (see next sub-section), a qualitative coding of the transcripts was performed using NVivo. The programme and development process of each project was reconstructed to understand the decision-making process throughout the development. The qualitative coding was extended by analysis of project-related documents (see Table 1). In addition, the findings were presented and debated at a feedback workshop in January 2019, with a group including civil servants and local experts (11 people). The critical feedback received during this event allowed us to sharpen our conclusions and recommendations.

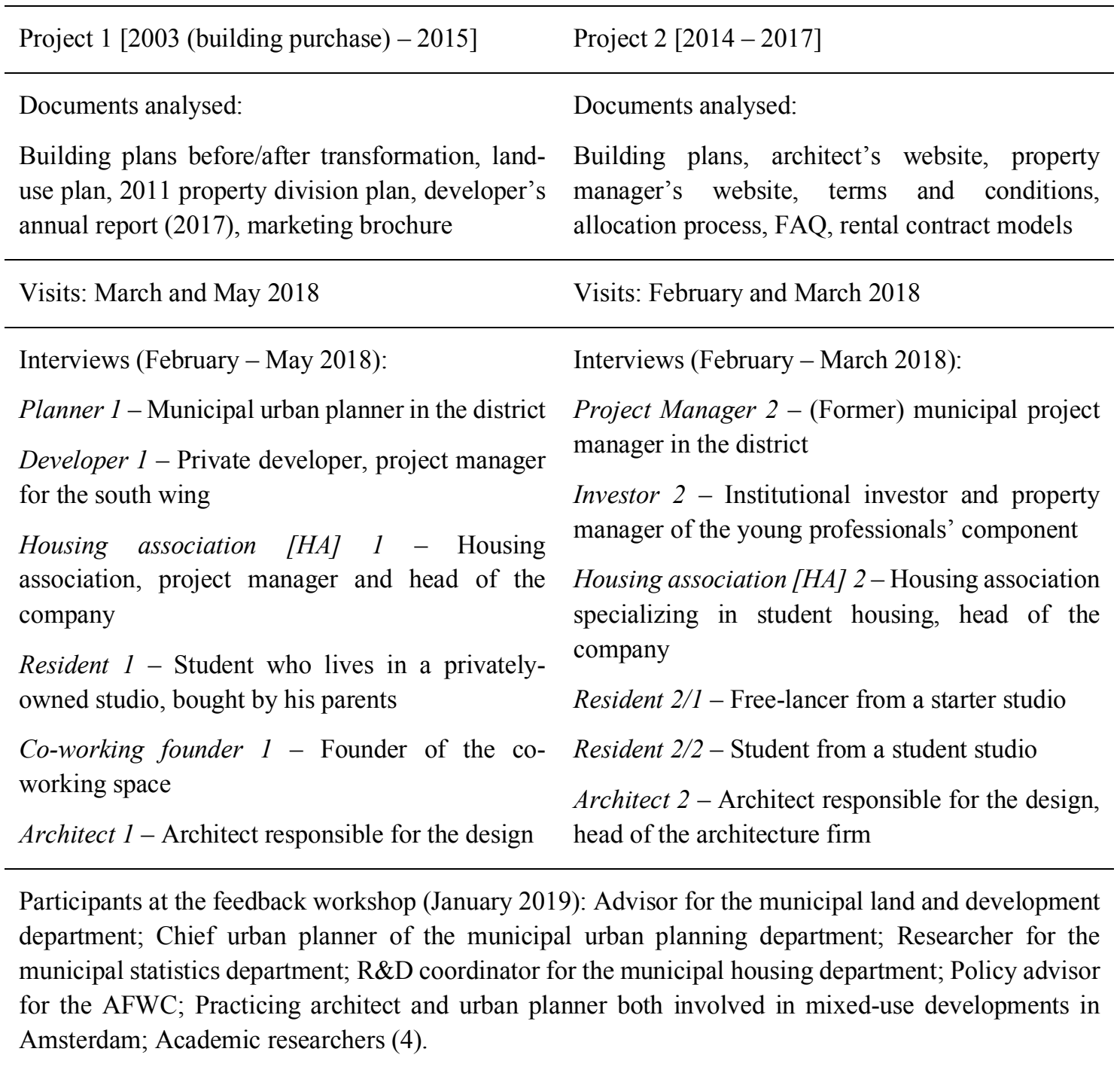

Table 1 Empirical material (documents, visits, interviews, feedback workshop) collected for each project 


\subsection{Understanding the governance of the shared housing market for students and young professionals: an analytical framework}

Our analysis draws upon an institutionalist approach to collaborative governance (Healey, 1997) in order to understand which governance arrangements, and especially which actors and instruments, are pertinent to the shared housing market (see Fig. 1).

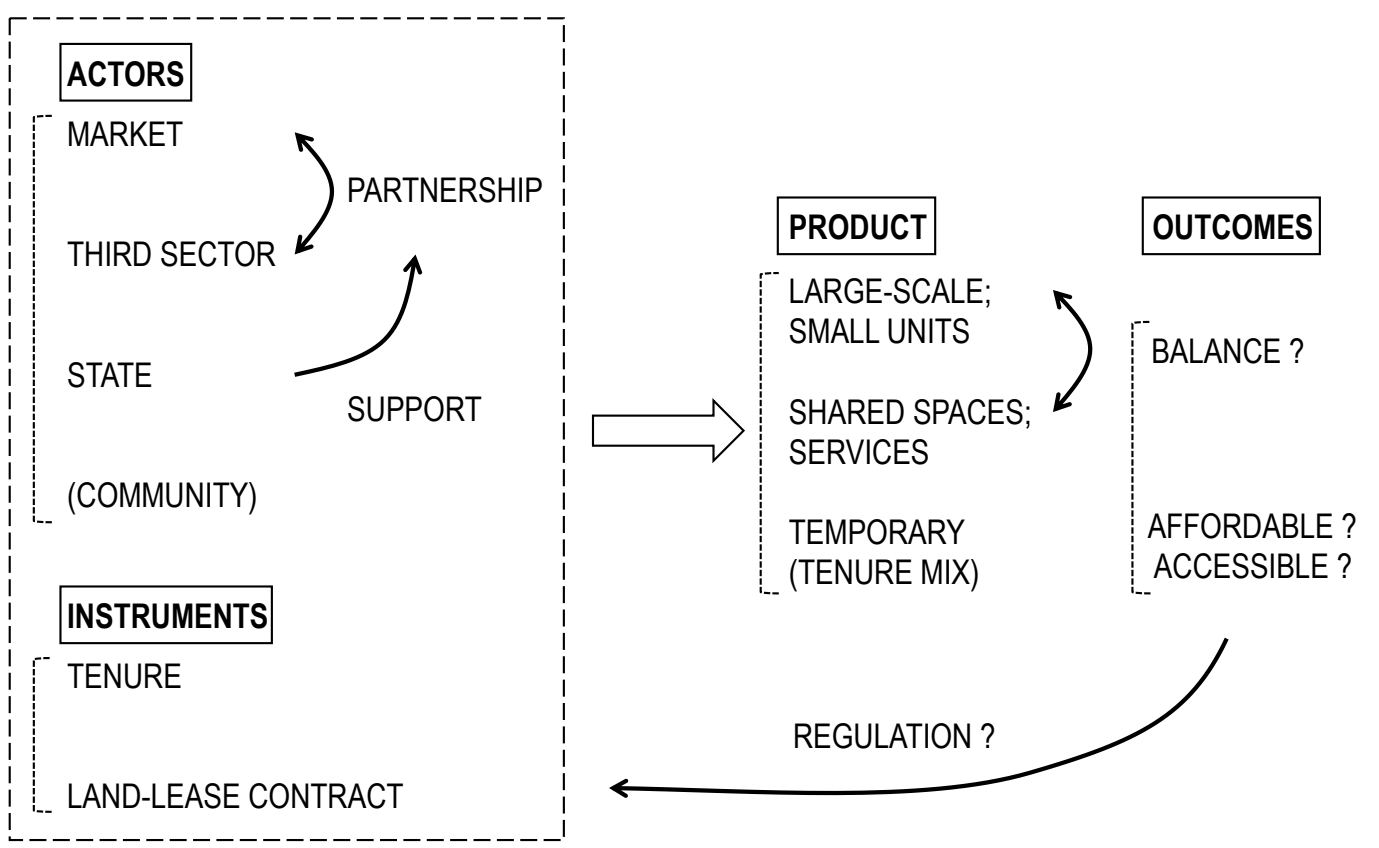

Fig. 1 Analytical framework representing the institutionalist approach used to study the governance of each project's development (actors and instruments), the product delivered, and the outcomes in terms of spatial balance between small dwellings and shared spaces, as well as housing affordability and accessibility of the dwellings

The actors are referred to according to their ideal-typical differentiation (market, state, community and third sector), to discuss their overlapping areas of means and interests (Brandsen, van de Donk, \& Putters, 2005). In both projects, real estate developers or institutional investors (market) and housing associations (third sector) collaborated to deliver a tenure mix, including social housing. On one hand, the real estate market, while also mitigating risks, is increasingly subject to speculative investment for short-term return (Landriscina, 2018), especially when regulatory policies are relaxed (Healey, 1997). On the other hand, housing associations (third sector), which are responsible for delivering social housing, have been constrained in their activities (see section 2.2). New tenure regulations allowed them to offer temporary rent to specific target groups. In a context of welfare state restructuring, including housing market deregulation, housing associations have been repositioned as 'hybrid organizations', encompassing public and private interests (Kleit, Airgood-Obrycki, \& Yerena, 2019). Beyond the 
partnership between the market and the third sector, the state also played a key role in our two cases. Amsterdam's local authorities have carefully supported housing developments aimed at students and young professionals, as would an 'entrepreneurial' state (e.g., Harvey, 1989). Especially during economic downturn, a municipality may have an interest in not only 'derisking' the private sector but also operating effectively in order to 'make things happen' (Mazzucato, 2013). Within this approach, public and private sectors are no longer considered as adversaries and state actions contribute to creating/supporting markets (ibid). In Amsterdam, underlying interests motivate support for the development of the shared housing market (see Sect. 4.2).

Tenure and planning instruments are the main tools used by these actors to align their interests and agree on the product to deliver. The emergence of mixed tenure and demands for new housing forms has led to more complex land and property markets (Healey, 1997). Our projects exemplify these changes, and the related interdependence of housing associations and market parties with their complementary abilities to address certain functions and tenures. These new alliances require new management and planning skills, and consensus-building (ibid). Amsterdam's spatial planning is intended to limit property owners' rights, but it has been increasingly supporting and participating in the creation of markets (Healey, 2007). In both our projects, the municipality of Amsterdam used powerful land-use planning instruments, such as land-lease and development contracts, to formalize the agreement negotiated with the developing team. This reduced risks for the market while safeguarding public services and facilities (TaşanKok et al., 2019). Furthermore, the choice of tenure, as a policy instrument, is an important step in decision-making and has effects on the housing market. The projects studied combine three different tenure forms with different levels of affordability and accessibility: (i) social housing for students, which is affordable but difficult to access (long waiting time), (ii) homeownership; i.e., the most secure tenure, but also difficult to access (conditions on mortgage, availability) and (iii) the PRS, which is increasingly unaffordable and insecure.

We finally discuss the outcomes of the projects in terms of spatial balance between small housing units and shared spaces, as well as housing affordability and accessibility of the dwellings. After reflecting on the success of the products delivered for the target group, we consider the potential contribution of shared facilities on the spatial quality of the developments. Shared spaces and services should balance the inconvenience of tiny and high-density living, by offering quality spaces for sociability and work or leisure activities (Ellen, 2015). Social interactions help connect people and further contribute to a sense of community (Reid, 2015). However, the concept of sharing common spaces can be utilized by the real estate market to target specific groups rather than foster community aspects (see section 2.2). Then, we discuss housing affordability, generally seen as the ratio of housing costs over income, and housing accessibility, or the 'ability of households to enter the housing market' (Kadi \& Musterd, 2015). To do so, we 
examine possible signs of market pressure, the tenant selection process and the form of tenurebased on the regulatory changes previously described - and we reflect on the related risks. In particular, a selective process can degrade accessibility and lead to more 'exclusive' housing markets (Grundström \& Molina, 2016).

The programme and the development process are described for each project, and the discussion is then structured as follows: (i) coalitions of actors involved, (ii) instruments used and (iii) reflection on the outcomes of the projects studied.

\section{Comparing two shared housing projects: results and discussion}

\subsection{Reconstruction of facts}

Project 1 (651 dwellings of $25-47 \mathrm{~m}^{2}, 40,000 \mathrm{~m}^{2}$ in total) is a conversion of large-scale offices into housing, with a mix of social housing for students (266 units) and privately-owned studios (385 units) for young professionals. The north wing (2013) includes a co-working space, a restaurant and a laundrette on the lower floors. Project 2 ( 869 dwellings, $45,000 \mathrm{~m}^{2}$ ) is a new construction, with a mix of social housing for students (590 units, $\left.24 \mathrm{~m}^{2}\right)$ and temporary privaterented studios ( 279 units, $41 \mathrm{~m}^{2}$ ) for young professionals. The ground floor is partly commercial and shared spaces (e.g., libraries, meeting rooms) as well as services were promised, specifically for the young professionals, during the commercialization phase, but still being furnished in spring 2018. Both projects are located on the western edge of the inner city, with project 2 being located next to a large railway station. The development process for each project is described in what follows.

Project 1. (Phase 1: Acquisition, 2003-2008). The developer bought the office building and formed a partnership with a housing association. Because the building was listed as a historic monument, they could not demolish it and were advised to reinvest in offices. (Phase 2: North wing, 2008-2013). The project was then put on hold due to the financial crisis. To reduce risks and release funds, the developing team decided to split the property development and to reestablish a land-lease with the municipality for the north wing. The latter was the first part to be transformed. The housing association decided to buy studios, pre-sale, for student housing. All studios were rapidly sold or rented out. (Phase 3: South wing, 2014-2015). The success of the north wing confirmed the demand for studios on the housing purchase market. The transformation of the south wing started next. In contrast to the north wing, this included no commercial space and a greater proportion of owner-occupied dwellings. The studios were also more expensive in comparison. In the same period, the co-working space opened in the north wing; all business units were soon occupied. (Phase 4: Middle part, 2015-2018). The middle part was sold to another 
investor, who, at the time of the data collection in 2018, was reported to have redeveloped it into housing and a short-stay hotel (Architect 1).

Project 2. (Phase 1: Previous project, before 2014). Before project 2, a high standing hotel and housing project was planned on the plot but these plans were withdrawn because of the real estate crisis resulting from the 2008 crisis. The investor, specializing in student housing, decided to work in partnership with a housing association with similar focus. (Phase 2: Negotiations and building permit, 2014-2015). The investor negotiated the student housing project with the municipality, who needed to get a financial return on investment for the plot after the other plans were cancelled (Project Manager 2). For the municipality, this large-scale development was also an opportunity to increase social control around the railway station, reported as unsafe, e.g., by Architect 2. Both the local alderman and the architectural review committee, for different reasons unconnected to the shared housing programme, were not in favour of the project (Project Manager 2). Nevertheless, the municipality allowed the project to start and made a development contract with the investor. (Phase 3: Construction and concept for young professionals, 2016-2017). Construction started when the real estate sector was recovering. The investor decided to also appeal to young professionals concomitantly with the introduction of new tenure regulations. During building construction, storage rooms were transformed into shared spaces. The marketing phase was an immediate success (Investor 2) and the student units were allocated within two days.

\subsection{Coalitions of actors}

The key actors in both projects (see the list of interviewees and their roles in Table 1) were traditionally involved in residential developments, but their collaboration generated interdependencies, especially between the market and the third sector, who had to align their agendas and resources. During the projects, economic developments (financial crisis) and legal changes, resulting among others from the political debate on the key tasks of housing associations, constrained their ability to invest, which obliged them to collaborate with private parties. In project 1, all decisions were reported to be made by the partners together (Developer 1). Developer 1 needed to mitigate their risks through pre-sales. Those risks were important given the heritage status constraining technical and programmatic choices, the long development period and the uncommon housing product. At the time, the housing association was still (before 2015) able to develop commercial activities (here, the co-working space) and accepted to buy dwellings for student housing (given the shortage for this group) after a compromise was found on the programme. The following quotes illustrate the actors' agreement on the programme and their common interest in mitigating development risks by combining their complementary abilities. 
"We agreed upon the programme. We really believed in building smaller units for the residents, and there was no discussion about architecture, so... And [Housing association [HA] 1] had also another role, because they were, as an institutional housing company, also buyer. And we were only developer." [Developer 1]

"We have decided to look if it is possible to make small housing for students. But it was only possible 'cause [Developer 1] is a commercial party, and we are social housing, so [Developer 1] doesn't want to start without selling any parts of this building." [HA 1]

Nevertheless, after the success of the first phase, Developer 1 decided to make the second phase purely residential and with less social housing, which increased the company's profit.

In project 2, the housing association involved was specialized in student housing and had already collaborated with investor 2 on previous student housing projects. However, it was in an uncomfortable position as it was not directly involved in the design and was, unusually, not the owner of the property, by lack of financial means (HA 2). For this project, Investor 2 had a clear interest in attracting internationals and young professionals, hence selecting candidates aged between 20 and 34, with an employment contract and a certain income. The company used formulations such as 'The Millennials Life Cycle' or 'Young Professional Living' on the project's website, as well as pictures with groups of young people making 'selfies', going to parties and practising sports, which further enhanced this narrative.

"Let me say, we have a mix of people living here, and that was our philosophy, we want a mix of different people. Dutch nationals but also internationals. (...) Let's see if we can attract those employees to the building, but in the same time, let's see if we can attract also the creative sector, young entrepreneurs. So, then, we have a great mix of people, and also bankers and lawyers, and whatever." [Investor 2]

The collaborative partnerships observed in the two projects thus offered a combination of the financial means to invest and the ability to provide subsidized student housing, as well as an acceptable risk balance.

The municipality actively supported both developments through the strategic use of planning instruments (see section 4.3). The city not only urgently needed a financial return on land investment in the crisis context, but also considered that these projects were the "right thing to do on the right place' (as reported a civil servant who was aware of the project during the feedback workshop). The municipality was indeed preoccupied with the housing shortage for students and young professionals, whom the city also designates as 'starters', 'urban nomads', 
'millennials', or 'young urban adults' (De Boer, 2020). The municipality was also worried about the areas concerned. Having a vacant building at the core of a neighbourhood with renewal goals was not positive for the city (Planner 1), nor was an empty plot on hold in an area already perceived as unsafe (Project Manager 2). This illustrates the broader interest of local planning authorities in real estate projects that are perceived as essential to redevelop neighbourhoods (Pfeiffer, Pearthree, \& Ehlenz, 2019).

"They had a presentation about it, and, yeah, in the municipality, it was like: 'Well, this is actually what we need, the programme at least with the big amount of people, who are also going to move there with the station area, to hopefully make the station, make it feel more safety (sic)..." [Project Manager 2]

"This was ok from the beginning, even though it was a large programme of housing, but $(\ldots)$ at that moment, there was not a lot of student housing in this whole area. (...) And there were no studios. And nowadays, there is a policy within Amsterdam because now they were made so many studios after this project, everywhere. And now we put up more effort in making more... Ja, differentiatie [Yes, differentiation] and other types of housing. But at that time, this was one of the first buildings where that was..." [Planner 1]

Both conspicuous (e.g., housing shortage) and underlying (e.g., attracting the target demographic or improving the area) interests, thus, encouraged the municipality to play an entrepreneurial role and support the creation of this market.

\subsection{Instruments used}

The land-lease and development contracts were the main planning instruments used by the municipality to support the projects. In particular, the land-lease contract, which is specific to the Netherlands and extensively used in Amsterdam (OECD, 2017), was strategically used to reduce the risks for the market actors involved. For instance, re-establishing a land-lease contract, after the municipality had bought a part of the land back, allowed releasing funds for the developing team in project 1.

"The municipality of Amsterdam also wanted this project to succeed, 'cause they saw this as a monument, they wanted to keep it. And they also wanted to give this area of Amsterdam a boost. (...) They made the possibility to make a land-lease contract, which made the project possible. So, there was a big effort done by the 
municipality to make this project work. (...) They really wanted to help us out, and to make the area better. And this was the way to do it." [Developer 1]

Similarly, negotiating a lower leasehold price and flexible quality requirements in a development contract, a 'one-to-one agreement' (Project Manager 2), facilitated the implementation of project 2. Planning could be used to incorporate specific demands (Revington et al., 2018) regarding e.g., unit sizes or the quality of shared spaces. However, the analysis of the outcomes (see below) shows that, in the crisis context, planning instruments were more used to make real estate projects happen than to enhance quality requirements.

Furthermore, in project 2, the investor opportunistically used the recent regulatory changes allowing temporary contracts (July 2016) to develop a new housing product, exclusively based on non-extendable short-term rental contracts. Given the housing shortage for young adults, the municipality supported this programme and let the market capture this regulation. Hence, while project 1, through its mix of student housing and studios for purchase, offers to young adults a spectrum of progress towards homeownership (Arundel \& Ronald, 2016), project 2 offers less security. Indeed, the PRS, especially if temporary, is seen as delivering less security to tenants (Hoolachan et al., 2017). Since the Amsterdam temporary housing regulation entered into force in July 2016, the long-term effects remain unknown.

\subsection{Outcomes}

In both projects, the 'product' delivered is a large-scale building with small housing, shared facilities and tenure mix, including temporary rent. Such a product responded to young adults' interest in having their own place, even though small (Verhetsel et al., 2017). Small housing was legitimized in both projects, but with different arguments, including the housing shortage and the presumed tenants' profile.

"The market for housing changed also a lot. People started to accept smaller flats than before. You know, to have a flat is more important than to have a big flat. (...) Younger people don't have much stuff anymore, they don't own books, because they read on the internet. So, the whole lifestyle was very important. I think people with, let's say, a lifestyle of 2005 would not have survived these flats. But people with a lifestyle of 2012, they did." [Architect 1]

In project 1, the numerous expressions of interest and rapid sales, with almost half of the buyers younger than 35 (Developer 1), attest to the success of these projects for the target group. Older age cohorts, including retired people, bought studios as well, but as an investment rather than a place to live (Co-working founder 1; Developer 1). 
The shared spaces and services were key to the development of small housing dwellings, to balance the inconvenience of tiny living. In project 1, a co-working space was delivered, which was uncommon at the time. The facilities were planned from the start to enhance mixed-use and respond to the residents' needs. Co-working companies, given their business model and expertise in new ways of working, get increasingly involved in new developments (Co-working founder 1) and might become key players in future developments. In contrast, the shared spaces developed in project 2 were inappropriate for their use (e.g., no daylight). These spaces were added during construction and seem to have merely served as a lately developed marketing concept for young professionals. The lack of quality of the shared spaces is not surprising since they were originally designed as storage spaces (Architect 2). Fair-quality shared spaces, however, would have helped compensate for limited space within the dwellings.

\begin{abstract}
"When I saw it [the shared working room] for the first time, it made me really disappointed about it. Because I think, for sure if they had windows, I would make more use of it. (...) Most of the time, I just work here in my room. (...) Especially on those days [when his girlfriend is also working from home], it's a downside that there's not a second room. Because then you can imagine that if you are sitting here the whole day, or if you were sitting with your boyfriend and you have to work the whole day in the same room, that can be, after all, a bit annoying." [Resident 2/1]
\end{abstract}

Growing housing pressure was observed in the projects studied and might threaten the affordability of the dwellings over time. Although both projects delivered a significant amount of social housing, the weak position of the housing associations in both partnerships attests to their progressive retreat under market pressure (Nieboer \& Gruis, 2016). Furthermore, in project 1, the overall affordability of the dwellings decreased rapidly. The apartments to buy were originally affordable, but vacancies and subletting were reported by several interviewees.

\footnotetext{
"You also see that a lot of the apartments that are owned by people... Like I think half of the people are not here, they AirBnB it, or they live outside of the city and they only use it a couple of days. (...) It's quite flexible how it's being used, I find." [Co-working founder 1]
}

Moreover, the second phase of development delivered apartments that were more expensive, and a rapid increase in sale prices was observed; e.g., with $€ 170,000$ for a studio in spring 2018 (online platform) against $€ 80,000$ in 2013 (Developer 1). Some young professionals who bought a studio expected such a short-term added value and had an active role in this process. 
"Another part of the market was young professionals, people who just graduated, had their first job in and around Amsterdam, but were not yet sure if they want to stay in Amsterdam for the rest of their career. Most of them were single. Imagine flight attendants, young lawyers, designers, people like that. (...) All of them were convinced they would be able to sell it for a better price and that's actually the case. Those flats are sold for more than double right now." [Architect 1]

While the social units have regulated rents, these observations raise concerns about speculation and further risk of gentrification (N. Smith, 2005), especially in this location on the edges of the inner city as has been observed in cities like London (Theurillat et al., 2015). Young people often anticipate neighbourhood change and are pioneers in locations that allow them to access official, stable housing sectors (Hochstenbach \& Boterman, 2015).

Finally, accessibility issues were illustrated in Project 2. The intrusive process of selecting young professionals for the apartments in the PRS component was directly handled by Investor 2, who is also the property manager. Investor 2 may have seen the overall process as virtuous in providing young people with housing in a context of housing shortage, but was not wholly comfortable with having to make this selection in line with his "commercial point of view" (Investor 2). Selecting tenants based on an expanding range of criteria, in a non-regulated housing segment, also potentially raises discrimination and privacy issues (Maalsen, 2020). In addition, this process suggests an exclusive target group and emphasizes new forms of housing, which promote 'housing as a form of distinction' (Grundström \& Molina, 2016).

\subsection{Highlights for the regulation of the shared housing market}

The analysis of the actors involved in two shared housing developments highlighted the shared interests and aligned means supporting a collaborative partnership between the market and the third sector. Mixed tenure and target groups justified the actors' combination of complementary abilities and investment capacities. Moreover, the products delivered matched the municipality's financial needs and goals to densify and upgrade the areas concerned through housing supply for young adults. The developments thus received active state support, through the strategic use of land-lease and development contracts. In one case, the market could also benefit from the introduction of temporary tenancy within Dutch renting law (Huisman, 2016b) to develop a more flexible (but less secure) shared housing product.

Our discussion of the project outcomes emphasized that the shared housing market delivers products that respond to young adults' interest in having their own place while sharing spaces for social interaction. We also pointed at the potential of shared spaces and services to balance the concentration of small housing dwellings, beyond serving marketing concepts. 
However, we raised affordability and accessibility issues in this market, even in developments including regulated housing segments, such as social housing. On one hand, housing affordability may be affected by increasing market pressure, possibly inducing speculative behaviours and risk of gentrification. On the other hand, housing accessibility may be threatened by intrusive tenant selection processes, which can foster exclusive housing. Based on these highlights, the final section provides some conclusions and recommendations.

\section{Conclusions and recommendations}

This paper addresses the shared housing market, that is, developments delivering hundreds of small dwellings with shared facilities, aimed at students and young professionals. This market emerged as a product of the concentration of young singles in cities, with a commodifying housing market, competition for highly-skilled workers and expansion of their housing supply through densification. These observations increasingly apply to Amsterdam. From our empirical study in this city, with an institutionalist approach to collaborative governance, we conclude that the coalitions of actors developing shared housing for students and young professionals can involve third-sector housing providers (e.g., housing associations) and market parties (developers and investors). These actors rely upon each other and receive the support of local governments, especially in times of economic downturn. Using (new) regulatory instruments is also essential to implement these developments. In Amsterdam, several projects of this kind were initiated in the aftermath of the real estate crisis, quickly delivering a large number of small apartments. With the first projects completed and the progressive growth of the shared housing market, the municipality started becoming aware of the potential drawbacks, notwithstanding evident benefits. The outcomes of the projects confirmed young adults' interest in this market, despite affordability and accessibility issues, and the need to improve shared space design.

Reflecting on the outcomes of the projects provides insights for the regulation of the shared housing market. Among governance instruments, focusing on regulation seems relevant in institutional frameworks with regulatory traditions, the effects of softer instruments being expected to be more limited and easily diverted, especially in a context of globalisation and commodification. In particular, we advocate for the creation of specific standards for shared space design in building regulations such as the Dutch building decree, in which shared spaces are not subject to explicit rules at present. Apart from regulation per se, new actors (e.g., co-working companies) and instruments could facilitate the operation of shared spaces, which would help reduce the implementation risks of shared housing developments. These measures could enhance the added value of shared spaces for the residents of tiny living space. Most importantly, this would avoid that shared facilities mostly serve the marketing of small housing and are marginalized when market pressure grows. Furthermore, given our concern about the 
affordability and accessibility of the shared housing market, we plea for further research on the long-term effects of this growing market segment and regulatory opportunities for improvement. Regulatory interventions at the local and/or national levels might be the most effective and easiest to implement in a context of housing commodification.

Although the shared housing market may have grown particularly rapidly in Amsterdam, we expect it to develop in other cities facing housing commodification and a housing shortage for young adults, both in the Netherlands and in other European countries. Other Dutch cities, including university cities and cities with a high housing demand, will be probably confronted to this growing phenomenon, given their difficulties to accommodate similar target demographics (Fang \& van Liempt, 2020; Hochstenbach et al., 2020). In other countries, the shared housing market is more likely to grow in liberal regimes such as the UK, where higher rates of shared housing arrangements have been observed (Arundel \& Ronald, 2016). Nevertheless, former welfare states such as Sweden, where a shift from universal to market-led housing provision occurred in the 1990s (Hedin, Clark, Lundholm, \& Malmberg, 2012), might experience similar developments to the ones observed in Amsterdam.

Our methodological choices (limited sample of carefully selected interviewees; qualitative analysis) may have limited opportunities for generalisation of the aforementioned findings. However, the selected methods were conditioned to the low availability of case studies, since the shared housing market is a growing but relatively new phenomenon. Besides, our contribution improves knowledge of the shared housing market from an institutionalist perspective focused on actors and instruments. It also gives insights for the regulation of this market and advocates for critical attention, from both academics and policy makers, to an emerging market segment which is likely to expand in the future.

\section{Acknowledgements}

We are thankful to the F.R.S-FNRS for funding this research, and to TU Delft and Amsterdam Institute for Advanced Metropolitan Solutions (AMS) for supporting the fieldwork period. We are also grateful to the anonymous reviewers for their valuable comments.

\section{Funding}

This work was supported by the F.R.S.-FNRS, Fund for Scientific Research [FRIA grant 21033]. 


\section{References}

AFWC. (2016). Jongerencontracten mogelijk per 1 juli 2016 [Youth contracts possible as from the 1st of July 2016]. Retrieved from http://www.afwc.nl/nieuws/nieuwsarchief/bericht/item/98/

Amsterdamse federatie van woningcorporaties [AFWC]. (2018). Jaarbericht 2018 [Annual report 2018].

Arundel, R., \& Ronald, R. (2016). Parental co-residence, shared living and emerging adulthood in Europe: semi-dependent housing across welfare regime and housing system contexts. Journal of Youth Studies, 19(7), 885-905. https://doi.org/10.1080/13676261.2015.1112884

Bergan, T. L., Gorman-Murray, A., \& Power, E. R. (2020). Coliving housing: home cultures of precarity for the new creative class. Social and Cultural Geography, 119. https://doi.org/10.1080/14649365.2020.1734230

Boelhouwer, P. (2019). The housing market in The Netherlands as a driver for social inequalities : proposals for reform. International Journal of Housing Policy, 0(0), 110. https://doi.org/10.1080/19491247.2019.1663056

Boelhouwer, P., \& Priemus, H. (2014). Demise of the Dutch social housing tradition: Impact of budget cuts and political changes. Journal of Housing and the Built Environment, 29(2), 221-235. https://doi.org/10.1007/s10901-013-9387-9

Bontje, M., \& Musterd, S. (2009). Creative industries, creative class and competitiveness: Expert opinions critically appraised. Geoforum, 40(5), 843-852. https://doi.org/10.1016/j.geoforum.2009.07.001

Bontje, M., Musterd, S., \& Sleutjes, B. (2017). Skills and cities: Knowledge workers in Northwest-European cities. International Journal of Knowledge-Based Development, 8(2), 135-153. https://doi.org/10.1504/IJKBD.2017.085152

Booi, H., \& Boterman, W. R. (2019). Changing patterns in residential preferences for urban or suburban living of city dwellers. Journal of Housing and the Built Environment. https://doi.org/10.1007/s10901-019-09678-8 
Boterman, W. R., \& van Gent, W. P. C. (2014). Housing Liberalisation and Gentrification: The Social Effects of Tenure Conversions in Amsterdam. Tijdschrift Voor Economische En Sociale Geografie, 105(2), 140-160. https://doi.org/10.1111/tesg.12050

Brandsen, T., van de Donk, W., \& Putters, K. (2005). Griffins or Chameleons? Hybridity as a Permanent and Inevitable Characteristic of the Third Sector. International Journal of Public Administration, 28(9-10), 749-765. https://doi.org/10.1081/PAD200067320

Bromley, R. D. F., Tallon, A. R., \& Roberts, A. J. (2007). New populations in the British city centre: Evidence of social change from the census and household surveys. Geoforum, 38(1), 138-154. https://doi.org/10.1016/j.geoforum.2006.07.008

Buitelaar, E., \& Sorel, N. (2010). Between the rule of law and the quest for control: Legal certainty in the Dutch planning system. Land Use Policy, 27(3), 983-989. https://doi.org/10.1016/j.landusepol.2010.01.002

CB Richard Ellis [CBRE]. (2018). Q1 2018. UK student accommodation: five big trends in 2018.

De Boer, J. (2020, January). De toekomst van de verdichte stad [The future of the densified city]. Plan Amsterdam, 28-32.

Dembski, S., Hartmann, T., Hengstermann, A., \& Dunning, R. (2020). Introduction. Enhancing understanding of strategies of land policy for urban densification. Town Planning Review, 91(3), 209-216. https://doi.org/10.3828/tpr.2020.12

Druta, O., \& Ronald, R. (2020). Living alone together in Tokyo share houses. Social and Cultural Geography, O0(00), 1-18. https://doi.org/10.1080/14649365.2020.1744704

Ellen, I. G. (2015). Housing Low-Income Households: Lessons From the Sharing Economy? Housing Policy Debate, 25(4), 783-784. https://doi.org/10.1080/10511482.2015.1042204

Fang, C., \& van Liempt, I. (2020). 'We prefer our Dutch': International students' housing 
experiences in the Netherlands. Housing Studies, 0(0), 1-21. https://doi.org/10.1080/02673037.2020.1720618

Fincher, R., \& Costello, L. (2005). Narratives of high-rise housing: Placing the ethnicized newcomer in inner Melbourne. Social and Cultural Geography, 6(2), 201-218. https://doi.org/10.1080/14649360500074634

Florida, R. (2002). The Rise of the Creative Class. The Washington Monthly, pp. 15-25.

Gemeente Amsterdam. (2017). Woonagenda 2025: Voldoende, betaalbare en goede woningen. Amsterdam.

Gemeente Amsterdam. (2019). Youth and Student Housing. Retrieved from https://maps.amsterdam.nl/jongerenstudentenhuisvesting/?LANG=en

González, S., \& Healey, P. (2005). A Sociological Institutionalist Approach to the Study of Innovation in Governance Capacity. Urban Studies, 42(11), 2055-2069. https://doi.org/10.1080=00420980500279778

Grundström, K., \& Molina, I. (2016). From Folkhem to lifestyle housing in Sweden: segregation and urban form, 1930s-2010s. International Journal of Housing Policy, 16(3), 316-336. https://doi.org/10.1080/14616718.2015.1122695

Harvey, D. (1989). From managerialism to entrepreneurialism: the formation of urban governance in late capitalism. Geografisker Annaler, 71B, 3-17.

Healey, P. (1997). Collaborative planning: Shaping places in fragmented societies. Macmillan Press Ltd. https://doi.org/10.1016/s0743-0167(97)00052-1

Healey, P. (2007). Urban Complexity and Spatial Strategies. Towards a relational planning for our times. (C. Hague, T. Richardson, \& R. Upton, Eds.). Oxon: Routledge.

Heath, S., \& Kenyon, L. (2001). Single Young Professionals and Shared Household Living. Journal of Youth Studies, 4(1), 83-100. https://doi.org/10.1080/1367626012002856

Hedin, K., Clark, E., Lundholm, E., \& Malmberg, G. (2012). Neoliberalization of 
Housing in Sweden: Gentrification, Filtering, and Social Polarization. Annals of the Association of American Geographers, 102(2), 443-463. https://doi.org/10.1080/00045608.2011.620508

Hochstenbach, C. (2016). State-led Gentrification and the Changing Geography of Market-oriented Housing Policies. Housing, Theory and Society, 6096(June 2017), 1-21. https://doi.org/10.1080/14036096.2016.1271825

Hochstenbach, C., \& Arundel, R. (2019). Spatial housing-market polarization: diverging house values in the Netherlands. CUS Working Paper Series - WPS-No. 36.

Hochstenbach, C., \& Boterman, W. R. (2015). Navigating the field of housing: housing pathways of young people in Amsterdam. Journal of Housing and the Built Environment, 30(2), 257-274. https://doi.org/10.1007/s10901-014-9405-6

Hochstenbach, C., \& Ronald, R. (2020). The unlikely revival of private renting in Amsterdam: Re-regulating a regulated housing market. Environment and Planning A: Economy and Space, (March), 0308518X2091301. https://doi.org/10.1177/0308518x20913015

Hochstenbach, C., Wind, B., \& Arundel, R. (2020). Resurgent landlordism in a student city: urban dynamics of private rental growth. Urban Geography, 00(00), 1-23. https://doi.org/10.1080/02723638.2020.1741974

Hoolachan, J., McKee, K., Moore, T., \& Soaita, A. M. (2017). 'Generation rent' and the ability to 'settle down': economic and geographical variation in young people's housing transitions. Journal of Youth Studies, 20(1), 63-78. https://doi.org/10.1080/13676261.2016.1184241

Hubbard, P. (2009). Geographies of studentification and purpose-built student accommodation: Leading separate lives? Environment and Planning A, 41(8), 19031923. https://doi.org/10.1068/a4149

Huisman, C. J. (2016a). A silent shift? The precarisation of the Dutch rental housing market. Journal of Housing and the Built Environment, 31(1), 93-106. https://doi.org/10.1007/s10901-015-9446-5 
Huisman, C. J. (2016b). Temporary tenancies in the Netherlands: from pragmatic policy instrument to structural housing market reform. International Journal of Housing Policy, 16(3), 409-422. https://doi.org/10.1080/14616718.2016.1195563

Jonkman, A. (2020). Patterns of distributive justice: social housing and the search for market dynamism in Amsterdam. Housing Studies, 0(0), 1-32. https://doi.org/10.1080/02673037.2020.1739232

Kadi, J., \& Musterd, S. (2015). Housing for the poor in a neo-liberalising just city: Still affordable, but increasingly inaccessible. Tijdschrift Voor Economische En Sociale Geografie, 106(3), 246-262. https://doi.org/10.1111/tesg.12101

Kemp, P. A. (2011). Low-income Tenants in the Private Rental Housing Market. Housing Studies, 26(7-8), 1019-1034. https://doi.org/10.1080/02673037.2011.615155

Kleit, R. G., Airgood-Obrycki, W., \& Yerena, A. (2019). Public Housing Authorities in the Private Market. Housing Policy Debate, 00(00), 1-23. https://doi.org/10.1080/10511482.2019.1582548

Landriscina, M. (2018). 'Seeing the blessings and beauty of real estate: examining how market professionals' lived space drives abstract space making'. Social and Cultural Geography, 00(00), 1-23. https://doi.org/10.1080/14649365.2018.1535086

Linde, M. A. J., Dieleman, F. M., \& Clark, W. A. V. (1986). Starters in the Dutch Housing Market. Tijdschrift Voor Economische En Sociale Geografie, 77(4), 243-250. https://doi.org/10.1111/j.1467-9663.1986.tb00131.x

Maalsen, S. (2020). ' Generation Share ': digitalized geographies of shared housing. Social \& Cultural Geography, 21(1), 105-113. https://doi.org/10.1080/14649365.2018.1466355

Mackie, P. K. (2016). Young people and housing: identifying the key issues. International Journal of Housing Policy, 16(2), 137-143. https://doi.org/10.1080/14616718.2016.1159273

Madden, D., \& Marcuse, P. (2016). In defense of housing: the politics of crisis. London: Verso. 
Mazzucato, M. (2013). The Entrepreneurial State. Debunking Public vs. Private Sector Myths. London: Anthem Press.

Meijer, R., \& Jonkman, A. (2020). Land-policy instruments for densification: The Dutch quest for control. Town Planning Review, 91(3), 239-258. https://doi.org/10.3828/tpr.2020.14

Moos, M. (2016). From gentrification to youthification? The increasing importance of young age in delineating high-density living. Urban Studies, 53(14), 2903-2920. https://doi.org/10.1177/0042098015603292

Muhammad, S., Ottens, H. F. L., Ettema, D., \& Jong, T. (2007). Telecommuting and residential locational preferences: A case study of the Netherlands. Journal of Housing and the Built Environment, 22(4), 339-358. https://doi.org/10.1007/s10901-007-9088-3

Nabielek, K. (2011). Urban densification in the Netherlands: National spatial policy and empirical research of recent developments. In The 5th International Conference of the International Forum on Urbanism (IFoU).

Nieboer, N., \& Gruis, V. (2016). The continued retreat of non-profit housing providers in the Netherlands. Journal of Housing and the Built Environment, 31(2), 277-295. https://doi.org/10.1007/s10901-015-9458-1

Nijënstein, S., Haans, A., Kemperman, A. D. A. M., \& Borgers, A. W. J. (2015). Beyond demographics: human value orientation as a predictor of heterogeneity in student housing preferences. Journal of Housing and the Built Environment, 30(2), 199217. https://doi.org/10.1007/s10901-014-9402-9

OECD. (2017). The Governance of Land Use in the Netherlands. The case of Amsterdam. https://doi.org/10.1787/9789264268791-en

Onderzoek Informatie en Statistiek [OIS]. (2017). Amsterdam in cijfers 2017.2: Bevolking en woningmarkt. [Amsterdam in figures 2017.2 - Population and Housing market.].

Pfeiffer, D., Pearthree, G., \& Ehlenz, M. M. (2019). Inventing what Millennials want 
downtown: housing the urban generation in low-density metropolitan regions. Journal of Urbanism, 12(4), 433-455. https://doi.org/10.1080/17549175.2019.1626267

Reid, S. (2015). Exploring social interactions and sense of community in multi-owned properties. International Journal of Housing Markets and Analysis, 8(4), 436-450. https://doi.org/10.1108/IJHMA-02-2015-0006

Revington, N., Moos, M., Henry, J., \& Haider, R. (2018). The urban dormitory: Planning, studentification, and the construction of an off-campus student housing market. $\begin{array}{llll}\text { International } \quad \text { Planning } & \text { Studies, } & 0(0), & 1-17 .\end{array}$ https://doi.org/10.1080/13563475.2018.1552565

Savini, F. (2016). Don't blame public law: The legal articulation of certainty in Amsterdam land-use planning. The Town Planning Review, 87(4), 459-479. https://doi.org/10.3828/tpr.2016.29

Savini, F., Boterman, W. R., van Gent, W. P. C., \& Majoor, S. (2016). Amsterdam in the 21st century: Geography, housing, spatial development and politics. Cities, 52, 103113. https://doi.org/10.1016/j.cities.2015.11.017

Smith, D. P., \& Hubbard, P. (2014). The segregation of educated youth and dynamic geographies of studentification. Area, 46(1), 92-100. https://doi.org/10.1111/area.12054

Smith, N. (2005). The new urban frontier. Gentrification and the revanchist city. (Routledge, Ed.), Progress in Human Geography (Routledge). London and New York. https://doi.org/10.1177/030913259702100327

Syntrus Achmea Real Estate \& Finance B.V. (2016). Outlook 2017-2019. Investing in Dutch real estate and mortgages. Amsterdam.

Tasan-Kok, T., Atkinson, R., \& Refinetti Martins, M. L. (2019). Complex planning landscapes: regimes, actors, instruments and discourses of contractual urban development. European Planning Studies, 27(6), 1059-1063. https://doi.org/10.1080/09654313.2019.1598018 
Theurillat, T., Rérat, P., \& Crevoisier, O. (2015). The real estate markets: Players, institutions and territories. Urban Studies, 52(8), 1414-1433. https://doi.org/10.1177/0042098014536238

Thomsen, J. (2007). Home experiences in student housing: About institutional character and temporary homes. Journal of Youth Studies, 10(5), 577-596. https://doi.org/10.1080/13676260701582062

Tummers, L. (2016). The re-emergence of self-managed co-housing in Europe: A critical review of co-housing research. Urban Studies, 53(10), 2023-2040. https://doi.org/10.1177/0042098015586696

Verhetsel, A., Kessels, R., Zijlstra, T., \& Van Bavel, M. (2017). Housing preferences among students: collective housing versus individual accommodations? A stated preference study in Antwerp (Belgium). Journal of Housing and the Built Environment, 32(3), 449-470. https://doi.org/10.1007/s10901-016-9522-5 